\title{
Diet of the Pacific Sand Lance (Ammodytes hexapterus) in the Salish Sea, British Columbia, in the 1960s
}

\author{
J. MARK HIPFNER ${ }^{1,3}$ and Moira GALBRAith ${ }^{2}$
}

${ }^{1}$ Wildlife Research Division, Environment Canada, R.R. 1, 5421 Robertson Road, Delta, British Columbia V4K 3N2 Canada ${ }^{2}$ Institute of Ocean Sciences, Ocean Sciences Division, 9860 West Saanich Road, Sidney, British Columbia V8L 4B2 Canada ${ }^{3}$ Corresponding author: mark.hipfner@ec.gc.ca

Hipfner, J. Mark, and Moira Galbraith. 2014. Diet of the Pacific Sand Lance (Ammodytes hexapterus) in the Salish Sea, British Columbia, in the 1960s. Canadian Field-Naturalist 128(1): 57-62.

The diet of the Pacific Sand Lance (Ammodytes hexapterus) was quantified from the stomach contents of 115 Pacific Sand Lance caught in the Strait of Georgia and Saanich Inlet (Vancouver Island) in the Salish Sea, British Columbia, in the spring and summer of 1966, in the Strait of Georgia in the spring and summer of 1967, and in the Strait of Georgia and Saanich Inlet in the spring and summer of 1968. There were 12 major taxa of prey in diets, 8 of which were Crustacea. Based on an index of relative importance, copepods were the dominant prey in 1966 and 1968, but not in 1967, when cladocerans, larvaceans, and teleosts also were common. The copepods Pseudocalanus spp. and Calanus marshallae were the only taxa to appear in diets in all three years. Pseudocalanus dominated the copepod component of diets in 1966, when sampling occurred in July; unspecified copepod nauplii (an early larval stage) were dominant in 1967 and 1968, when sampling occurred earlier (April to June). With the profound changes that have occurred in the Salish Sea over recent decades, these data can serve as a baseline for comparison.

Key Words: Pacific Sand Lance; Ammodytes hexapterus; diet; interannual variation; decadal variation; Strait of Georgia; Salish Sea; British Columbia

\section{Introduction}

In marine systems of the temperate northern hemisphere, the six species of sand lances (Ammodytes spp.) often act as important trophic links between zooplankton and the broad suite of predators that feed on small forage fishes (Wanless et al. 2005). The energy densities, growth rates, and fecundity of sand lances all vary spatially and temporally (Robards et al. 2002; Wanless et al. 2005), and this suggests that feeding conditions for sand lances can be highly variable.

The Pacific Sand Lance (Ammodytes hexapterus) is a vital component of northeastern Pacific Ocean food webs (Beacham 1986; Borstad et al. 2011). Despite its ecological importance, however, information on the diet of this species is extremely limited. A recent study quantified the diet of the Pacific Sand Lance at several sites along British Columbia's outer coast in the summers of 2009, 2010, and 2011 (Hipfner and Galbraith 2013).

Here, we have collated and analyzed data collected in the protected inner waters of the Salish Sea in the spring and summer of 1966, 1967, and 1968 (Barraclough and Fulton 1968a*, 1968b*; Barraclough et al. 1968*; Robinson et al. 1968*; Robinson 1969*). Because the Salish Sea ecosystem has undergone dramatic changes since that time (Therriault et al. 2009), these data can serve as a baseline for comparison.

\section{Methods}

Pacific Sand Lance were collected in surface trawls in waters of the Salish Sea off the coast of British Columbia: 8 were collected between 4 and 8 July 1966 in the Strait of Georgia and Saanich Inlet (southern Vancouver Island), 26 were collected between 5 and 9 June
1967 in the Strait of Georgia, and 81 were collected between 23 April and 7 June 1968 in the Strait of Georgia and Saanich Inlet. The gastrointestinal tracts of the 115 Pacific Sand Lance were excised with scalpel and forceps and were placed in vials filled with $15 \%$ buffered formalin.

In the laboratory, the excised tracts were washed over a $0.063 \mathrm{~mm}$ mesh to remove the formalin, which was captured for neutralization treatment and disposal. Each stomach was then separated out, transferred to a $1 \mathrm{~mm}$ gridded Petrie dish, and slit longitudinally under a Wild M4 dissecting microscope with ocular micrometer. The contents were removed using water from a squeeze bottle and then the items were counted. Their life stage was determined and they were identified to the lowest taxonomic level possible. Some stomach contents were fresh and in a condition that allowed the prey to be identified to species, but most contents had been at least partially digested. As a result, the representation of soft-bodied prey types such as larvaceans in diets could have been underestimated (Barraclough and Fulton 1968a*, 1968b*; Barraclough et al. 1968*; Robinson et al. 1968*; Robinson 1969*).

For this report, dry weight estimates were assigned to each species and stage based on weight vs. length regressions from Fulton (1968) and McCauley (1984), as well as direct lab measurements. Total length was used for most prey items, the exceptions being fork length in the case of larval fish and prosome length in the case of copepods.

To facilitate direct comparison with information collected elsewhere in British Columbia, we analyzed the data as described in Hipfner and Galbraith (2013). An 
index of relative importance (Pinkas et al. 1971) was calculated to quantify the importance of each prey type in Pacific Sand Lance diets in each year. The formula is:

(1) $I_{\mathrm{RI}}=$ the proportion of all non-empty stomachs that contained prey type $(i) \times$ (the proportion by number of prey type $(i)$ item relative to all prey types + the proportion by dry mass of prey type (i) relative to all prey types).

Following Santic et al. (2012), we then standardized this index for each prey type to a scale of $0-100$ using the formula:

(2) $\% I_{\mathrm{RI}}=100 \times\left[I_{\mathrm{RI}} \times\left(\sum I_{\mathrm{RI}}{ }^{-1}\right)\right]$.

When a predator consumes exclusively small prey, there tend to be strong correlations among the three component measures of $I_{\mathrm{RI}}$ (percentage frequency of occurrence, percentage by number of individual prey items, and percentage mass of prey), and these correlations can exaggerate differences in the importance of prey types (Macdonald and Green 1983). Therefore, we also report each of the three component measures for all prey types that constituted $10 \%$ or more of the $\% I_{\mathrm{RI}}$ in at least one of the three years.

\section{Results}

The fork lengths of the collected Pacific Sand Lance varied from 10 to $115 \mathrm{~mm}$, with the mean fork length being longer the later in the season that sampling oc- curred (Figure 1). Based on Figure 5 in Blackburn and Anderson (1997*) and Figure 7 in Robards et al. (2002), we assume that all Pacific Sand Lance sampled in 1966 and 1968 were young-of-year fish (age 0), as were the vast majority in 1967 (those $<100 \mathrm{~mm}$ in fork length). Food was found in the stomachs of all but 1 of the 115 Pacific Sand Lance, the lone exception occurring in 1967.

Across the three years, there were 12 major taxa of prey in Pacific Sand Lance stomachs, including 8 groups of crustaceans, as well as trematodes, molluscs, larvaceans (plankton), and teleosts (fish). However, prey from only 2 (in 1968), 4 (1966), and 10 (1967) of the 12 major taxa were present in any one year (Table 1). Of the 12 major taxa, copepods were by far the dominant group in $1966\left(\% I_{\mathrm{RI}}=97.0\right)$ and $1968(99.9)$, but not in 1967 (21.5), when cladocerans (33.1), larvaceans (18.0), and teleosts (25.7) also were common (Figure 2) (Table 2).

The copepods Pseudocalanus spp. and Calanus pacificus were the only prey types recorded in all three years (Table 1). In considering just the copepod component of the diet of the Pacific Sand Lance, Pseudocalanus dominated in $1966\left(\% I_{\mathrm{RI}}=72.8\right)$, whereas unspecified copepod nauplii dominated in both 1967 $\left(\% I_{\mathrm{RI}}=72.0\right)$ and $1968\left(\% I_{\mathrm{RI}}=64.1\right)$ (Table 3$)($ Figure 3). Three large calanoids-Calanus pacificus,

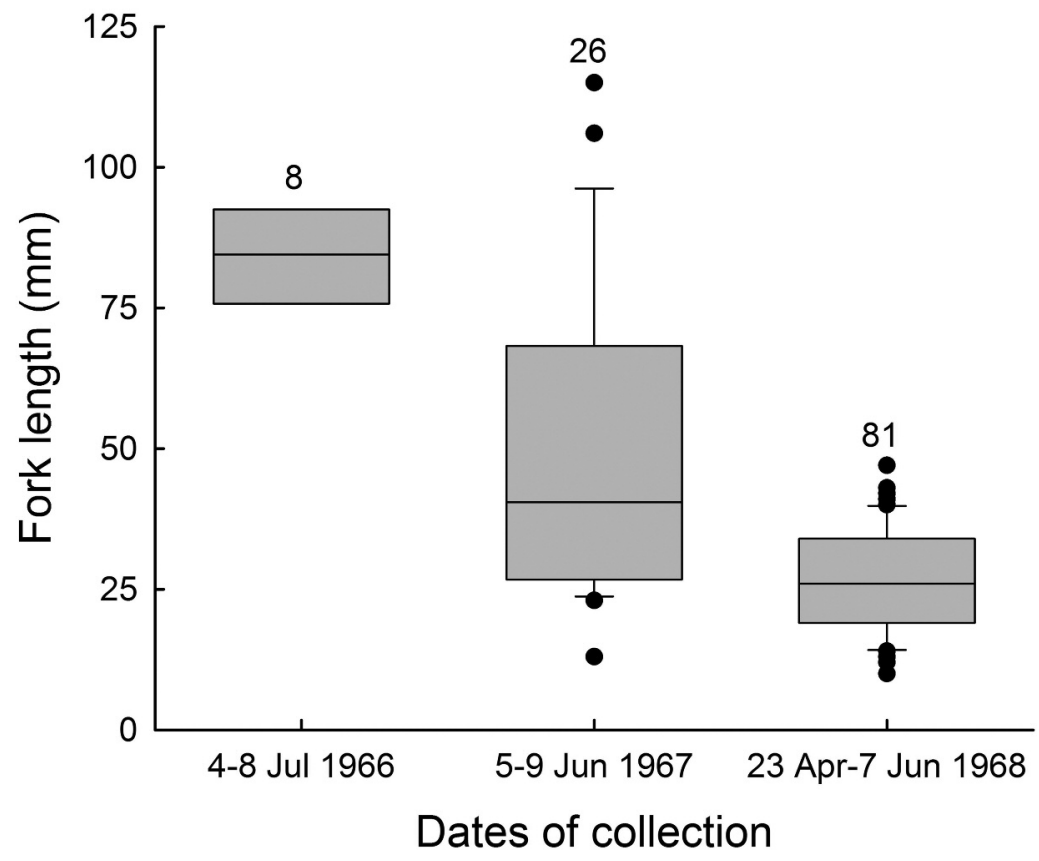

FIgURE 1. Fork lengths of Pacific Sand Lance (Ammodytes hexapterus) collected in trawl surveys in the Salish Sea, British Columbia, in relation to the date of sampling. Box plots show means, 25th and 75th percentiles, 5th and 95th percentiles (whiskers), and outliers. Sampling occurred from 4 to 8 July 1966 in the Strait of Georgia and Saanich Inlet, from 5 to 9 June 1967 in the Strait of Georgia, and from 23 April to 7 June 1968 in the Strait of Georgia and Saanich Inlet. 
TABle 1. Prey taxa and life stages recorded in the stomach contents of Pacific Sand Lance (Ammodytes hexapterus) in the Salish Sea, British Columbia, in 1966-1968.

\begin{tabular}{|c|c|c|c|c|}
\hline Major taxa & Sub-type/species & $1966(n=8)$ & $1967(n=26)$ & $1968(n=81)$ \\
\hline Trematodes & - & 0 & Yes & 0 \\
\hline $\begin{array}{l}\text { Molluscs } \\
\text { Crustaceans }\end{array}$ & Pelecypoda & 0 & Yes & 0 \\
\hline \multirow[t]{2}{*}{ Cirripeds } & Barnacle & 0 & Yes (nauplii) & 0 \\
\hline & Balanus & 0 & Yes (eggs) & 0 \\
\hline Cladocerans & Podon & Yes & Yes & 0 \\
\hline Ostracods & Alacia minor & 0 & Yes & 0 \\
\hline \multirow[t]{9}{*}{ Copepods } & Copepod & 0 & $\begin{array}{l}\text { Yes (eggs, nauplii, } \\
\text { copepodites) }\end{array}$ & $\begin{array}{l}\text { Yes (eggs, nauplii, } \\
\text { copepodites) }\end{array}$ \\
\hline & Acartia longiremis & Yes & 0 & 0 \\
\hline & Calanus pacificus & Yes & Yes & Yes \\
\hline & Microcalanus & 0 & 0 & Yes \\
\hline & Pseudocalanus & Yes & Yes & Yes \\
\hline & Cyclopoid & 0 & Yes & 0 \\
\hline & Neocalanus plumchrus & 0 & Yes & 0 \\
\hline & Scolecithricella minor & Yes & 0 & 0 \\
\hline & Paraeuchaeta elongata & 0 & 0 & Yes \\
\hline Hyperiids & Themisto pacifica & 0 & Yes & 0 \\
\hline Mysids & - & Yes & 0 & 0 \\
\hline Euphausiids & Euphausiid & 0 & 0 & Yes (eggs) \\
\hline Decapods & Brachyuran & Yes (zoea) & Yes (megalops) & 0 \\
\hline Larvaceans & Oikopleura & 0 & Yes & 0 \\
\hline Teleostei & - & 0 & Yes & 0 \\
\hline
\end{tabular}

Neocalanus plumchrus, and Paraeuchaeta elongatawere the dominant copepods in terms of mass in 1966, 1967, and 1968, respectively, despite being present in small numbers and in few stomachs-especially $P$. elongata (Figure 3) Although Paraeuchaeta elongata constituted $44.97 \%$ of the copepod component of

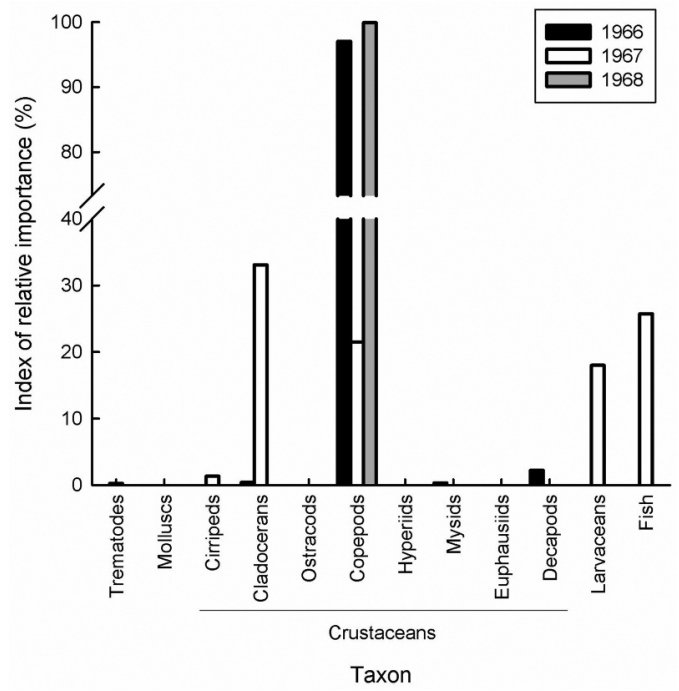

FIGURE 2. Indices of relative importance $\left(\% I_{\mathrm{RI}}\right)$ of the 12 major taxa of prey consumed by Pacific Sand Lance (Ammodytes hexapterus) in the Salish Sea, British Columbia, in each of three years $(1966,1967$, and 1968). diets in terms of mass in 1968, it was present in very small numbers $(2.50 \%)$ in very few stomachs $(2.75 \%)$ and thus had $\% I_{\mathrm{RI}}$ of $<2 \%$. Scolecithricella minor (in 1966) and unspecified copepodites (in 1968) were the only other prey that constituted $\geq 10 \%$ of copepod $\% I_{\mathrm{RI}}$ in at least one of the three years (Table 3) (Figure 3).

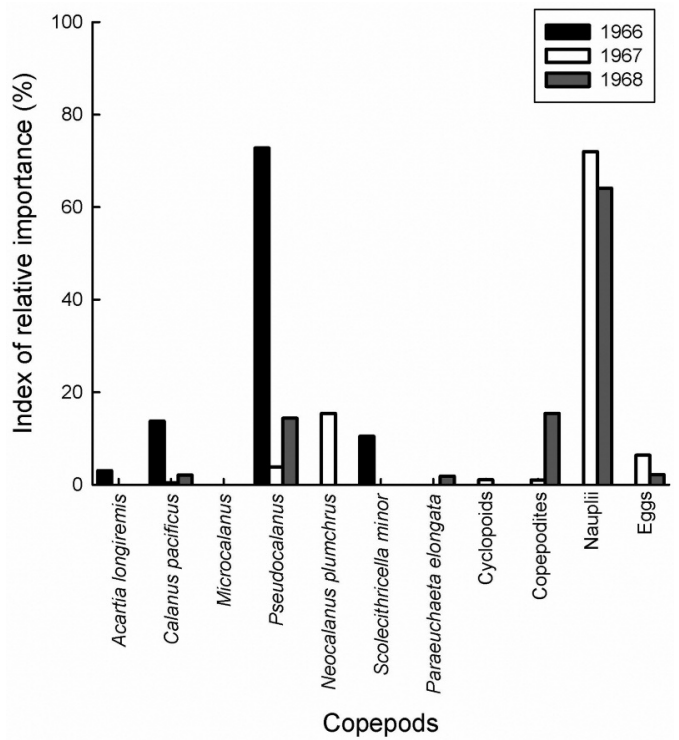

FIGURE 3. Indices of relative importance $\left(\% I_{\mathrm{RI}}\right)$ of the 11 taxa and life stages of unspecified copepod prey consumed by Pacific Sand Lance (Ammodytes hexapterus) in the Salish Sea, British Columbia, in each of three years (1966, 1967, and 1968). 

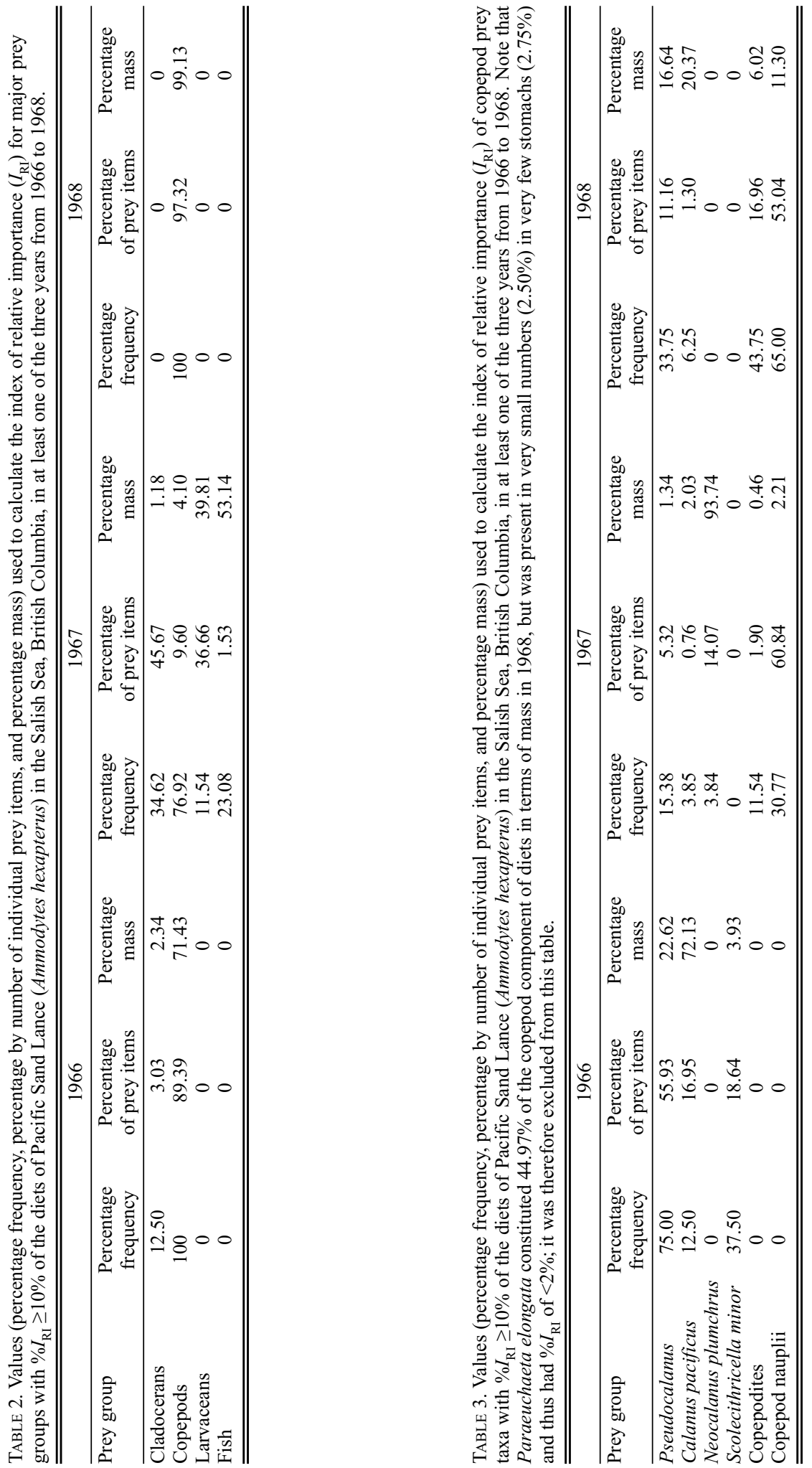


\section{Discussion}

The Pacific Sand Lance is a vital component of northeastern Pacific Ocean food webs (Beacham 1986; Gjerdrum et al. 2003), so there is need for a thorough understanding of its trophic relations. In the protected inner waters of the Salish Sea, 12 major prey taxa were found in its diet: 8 crustacean groups, plus trematodes, molluscs, larvaceans, and teleosts. This suite of prey taxa is similar to that reported for other species of sand lances (Scott 1973; Sekiguchi 1977; Richards 1982) and for the Pacific Sand Lance elsewhere (Blackburn and Anderson 1997*), including at four sites along British Columbia's outer coast (Hipfner and Galbraith 2013). Further, with one exception, in which mysids were the main prey type (O'Connell and Fives 1995), calanoid copepods were the primary prey of sand lances in all studies, so it was interesting that a more balanced array of prey, also including cladocerans, larvaceans, and teleosts, was taken in one of the three years of this study (1967).

The diet of the Pacific Sand Lance along British Columbia's outer coast included a broader array of copepod taxa and different life stages (Hipfner and Galbraith 2013) than in the Salish Sea (this study). Pseudocalanus (especially in the north) and Calanus marshallae (especially in the south) were the primary prey along the outer coast. Pseudocalanus was the primary prey in only one of the three years in the Salish Sea, and C. marshallae was not found at all. Copepod nauplii, the main prey of Pacific Sand Lance in two of the three years in the Salish Sea, occurred in trace amounts in just 2 of 12 site-years along the outer coast.

The differences between the two sets of studies could reflect any or all of four factors: (1) four decades separate them; (2) the age and size structure of the Pacific Sand Lance differed, with the outer coast study including only Pacific Sand Lance $>100 \mathrm{~mm}$ fork length; (3) the timing of sampling differed (April to early July in the Salish Sea and July to early August along the outer coast); and (4) the copepod communities of the Salish Sea and the outer coast differ.

We cannot assess the role that changes in the marine environment over time may have played, but there is reason to believe that all three of the remaining factors were involved. First, sand lance diets vary with age and size (O'Connell and Fives 1995); for example, the amount of the larger $C$. marshallae consumed by Pacific Sand Lance increased with fork length, while the amount of the smaller Pseudocalanus did not (Hipfner and Galbraith 2013). Second, the fact that copepod nauplii (an early larval stage) were very common in diets in the Salish Sea in both years when sampling occurred in spring but not in any year in the Salish Sea or along the outer coast when sampling occurred in summer implies that seasonal timing is a factor. And lastly, the summertime copepod community of the Salish Sea is dominated by small copepods, including Pseudocalanus (Sastri and Dower 2009), which was the primary prey of Pacific Sand Lance in July 1966, whereas Pseudocalanus and Calanus marshallae, the dominant prey along the outer coast in all three years of study (2009, 2010, and 2011) (Hipfner and Galbraith 2013), are two of the three most abundant zooplankters in continental shelf waters from Oregon to the Bering Sea (Mackas and Coyle 2005).

\section{Acknowledgements}

We thank W. Barraclough, J. Fulton, and D. Robinson, all of the Fisheries Research Board of Canada, for conducting the trawl surveys (which were also funded by the Fisheries Research Board of Canada) in the 1960s, and we thank the students from the South Hampton Work Experience Program for transcribing their data. Thanks also to T. Gaston for commenting on a previous draft of the paper.

\section{Documents Cited (marked * in text)}

Barraclough, W. E., and J. D. Fulton. 1968a. Number, size composition and food of larval and juvenile fish caught with a two-boat surface trawl in the Strait of Georgia July 4-8, 1966. Fisheries Research Board of Canada Manuscript Report Series No. 940.

Barraclough, W. E., and J. D. Fulton. 1968b. Food of larval and juvenile fish caught with a surface trawl in Saanich Inlet during June and July 1966. Fisheries Research Board of Canada Manuscript Report Series No. 1003.

Barraclough, W. E., D. G. Robinson, and J. D. Fulton. 1968. Number, size composition, weight, and food of larval and juvenile fish caught with a two-boat surface trawl in Saanich Inlet April 23-July 21, 1968. Fisheries Research Board of Canada Manuscript Report Series No. 1004.

Blackburn, J. E., and P. J. Anderson. 1997. Pacific Sand Lance growth, seasonal availability, movements, catch variability, and food in the Kodiak-Cook Inlet area of Alaska. University of Alaska Sea Grant College Program Report No. 97-01.

Robinson, D. G. 1969. Number, size composition, weight and food of larval and juvenile fish caught with a two-boat surface trawl in the Strait of Georgia April 24-25, 1968. Fisheries Research Board of Canada Manuscript Report Series No. 1067.

Robinson, D. G., W. E. Barraclough, and J. D. Fulton. 1968. Number, size composition, weight and food of larval and juvenile fish caught with a two-boat surface trawl in the Strait of Georgia June 5-9, 1967. Fisheries Research Board of Canada Manuscript Report Series No. 972.

\section{Literature Cited}

Beacham, T. D. 1986. Type, quantity and size of food of Pacific salmon Oncorhynchus in Strait of Juan-de-Fuca, British Columbia, Canada. Fishery Bulletin 84: 77-90.

Borstad, G., W. Crawford, J. M. Hipfner, R. Thompson, and K. Hyatt. 2011. Environmental control of the breeding success of rhinoceros auklets at Triangle Island, British Columbia. Marine Ecology Progress Series 424: 285-302.

Fulton, J. 1968. A laboratory manual for the identification of British Columbia marine zooplankton. Fisheries Research Board of Canada Technical Report 55.

Gjerdrum, C., A. M. J. Vallée, C. Cassady St. Clair, D. F. Bertram, J. L. Ryder, and G. S. Blackburn. 2003. Tufted puffin reproduction reveals ocean climate variability. Pro- 
ceedings of the National Academy of Sciences 100: 93779382.

Hipfner, J. M., and M. Galbraith. 2013. Spatial and temporal variation in the diet of the Pacific sand lance Ammodytes hexapterus in waters off the coast of British Columbia, Canada. Journal of Fish Biology 83: 1094-1111.

Macdonald, J. S., and R. H. Green. 1983. Redundancy of variables used to describe importance of prey species in fish diets. Canadian Journal of Fisheries and Aquatic Sciences 40: 635-637.

Mackas, D. L., and K. O. Coyle. 2005. Shelf-offshore exchange processes, and their effects on mesozooplankton biomass and community composition patterns in the northeast Pacific. Deep-Sea Research II 52: 707-725.

McCauley, E. 1984. The estimation of the abundance and biomass of zooplankton in samples. Pages 228-265 in A Manual on Methods for the Assessment of Secondary Productivity in Fresh Waters. Edited by J. A. Downing and F. H. Rigler. Blackwell Scientific, Boston, Massachusetts.

O'Connell, M., and J. M. Fives. 1995. The biology of the lesser sand-eel Ammodytes tobianus L. in the Galway Bay area. Biology and Environment 95: 87-98.

Pinkas, L., M. S. Oliphant, and I. L. K. Iverson. 1971. Food habits of albacore, bluefin tuna and bonito in California waters. Fisheries Bulletin 152: 1-105.

Richards, S. W. 1982. Aspects of the biology of Ammodytes americanus from the St. Lawrence River to Chesapeake Bay, 1972-75, including a comparison of the Long Island Sound postlarvae with Ammodytes dubius. Journal of the Northwest Atlantic Fisheries Society 3: 93-104.
Robards, M. D., J. Anthony, G. A. Rose, and J. F. Piatt. 2002. Changes in proximate composition and somatic energy content for Pacific Sand Lance (Ammodytes hexapterus) from Kachemak Bay, Alaska, relative to maturity and season. Journal of Experimental Marine Biology and Ecology 242: 245-258

Santic, M., B. Rada, and A. Pallaoro. 2012. Diet and feeding strategy of thornback ray Raja clavata. Journal of Fish Biology 81: 1070-1084.

Sastri, A. R., and J. F. Dower. 2009. Interannual variability in chitobiase-based production rates of the crustacean zooplankton community in the Strait of Georgia. Marine Ecology Progress Series 388: 147-157.

Scott, J. S. 1973. Food and inferred feeding behavior of northern sand lance (Ammodytes dubius). Journal of the Fisheries Research Board of Canada 30: 451-454.

Sekiguchi, H. 1977. Further observations on the feeding habits of planktivorous fish sand-eel in Isle Bay. Bulletin of the Japanese Society of Scientific Fisheries 43: 417422.

Therriault, T. W., D. E. Hay, and J. F. Schweigert. 2009. Biological overview and trends in pelagic forage fish abundance in the Salish Sea (Strait of Georgia, British Columbia). Marine Ornithology 37: 3-8.

Wanless, S., M. P. Harris, P. Redman, and J. R. Speakman. 2005. Low energy values of fish as a probable cause of a major seabird breeding failure in the North Sea. Marine Ecology Progress Series 294: 1-8.

Received 24 September 2013

Accepted 8 November 2013 